[J. Jpn. Soc. Starch Sci., Vol.34, No.3, p. 203 210 (1987)]

\title{
Polarographic and Liquid Chromatographic Analyses of Quinoxalines Derived from $\beta-1,3$ or $\beta-1,3$ and $\beta-1,6$ Glucans under Alkaline Conditions with Heating
}

\author{
Masanosuke Takagi, Kazuo Tsuchiya, Masao Kuriyama, \\ Keiichi MiYano and Naofumi MORITA \\ Department of Agricultural Chemistry, College of Agriculture, \\ University of Osaka Prefecture \\ (Mozuume-machi, Sakai, Osaka 591, Japan)
}

(Received January 26, 1987)

\begin{abstract}
We applied the alkaline $o$-phenylenediamine (OPD) method to $\beta$-1,3-linked glucans such as curdlan, scleroglucan and schizophyllan in alkaline media under heating and deoxygenated conditions. In the case of curdlan and laminari-oligosaccharide, $\left(2^{\prime} S, 3^{\prime} R\right)-2-\left(2^{\prime}, 3^{\prime}, 4^{\prime}\right.$-trihydroxybutyl) quinoxaline (G-1) was formed from the glucose residues in the main-chain, and several quinoxaline derivatives including G-1 from the non-reducing end groups. In the case of scleroglucan, G-1 was formed from $\beta-1,3$ linked sugar residues in the main-chain, and a quinoxaline, designated as QD-I, from the branching disaccharide units. The scleroglucan tested had a branch at intervals of every $2.3-2.6$ glucose units along the main-chain residue.
\end{abstract}

In our previous study on the degradation of carbohydrates in alkaline media, we used an alkaline $o$-phenylenediamine (OPD) method for the formation of quinoxaline derivatives, because of the stability of the derivatives and the ease of their spectrophotometric assaying. ${ }^{1 \sim 3)}$

In quinoxaline formation from $\alpha-1,4$ glucans such as amylose and maltodextrin ${ }^{4 \sim 6)}$ under alkaline-heated conditions, the reaction proceeds along the glucosyl chain from the reducing-end residue. Measurement of polarographic wave heights of the quinoxalines formed is a simple way to determine the amount of carbohydrate degraded. With this alkaline OPD method, the rate of quinoxaline formation is proportional to the number of reducing-end residues, and the reaction proceeds in a pseudo-zero-order manner in the presence of excess OPD. ${ }^{4)}$

Calculation of the degree of polymerization of 1,3-glucan is difficult since it does not easily dissolve in aqueous media. ${ }^{7)}$ The alkaline OPD method is useful for linkage analysis of glucans such as $\beta-1,3$ glucans. To evaluate this method, we examined some hetero- and homo-glucans, In this paper, we describe the separation of quinoxaline derivatives: and the quantitative assaying of quinoxalines formed from laminarioligosaccharides and scleroglucans. We also tried to determine the ratio of the degree of branching of the scleroglucans.

\section{MATERIALS AND METHODS}

Materials. Curdlan" [mean degree of polymerization $(\overline{\mathrm{d} \cdot \mathrm{p} . \mathrm{n}}), 400]$ was a generous gift from Prof. T. Harada, Kobe Women's University. Schizophyllan was kindly donated by Dr. S. Kikumoto, Taito Co. Scleroglucan was a product of Sclerotinia sclerotiorum IFO 5913 and 5292.8) Sclerotan was an acid-hydrolyzate $(\overline{\mathrm{d} . \mathrm{p} .} \mathrm{n}=16)$ of a product of Sclerotinia libertia$n a,{ }^{9)}$ kindly donated by Prof. M. Kitahara, Gifu University. Turanose (3-O- $\alpha$-D-glucosyl-D-fructose) was obtained from Yoneyama Chemical Industries Ltd., and used as a reference $\beta-1,3$ glucan. Luteose was kindly donated by Dr. Y. Takasaki, the Fermentation Research Institute. 
$\beta-1,3$ Glucanase was a product of a Basidiomycetes, ${ }^{10)}$ and kindly donated by Dr. M. Mada, Yakult Manufacturing Co., Ltd. OPD was purchased from Merck, AG. Other reagents were of the purest grade available from commercial sources.

Quinoxalines G-1 $\left[\left(2^{\prime} S, 3^{\prime} R\right)-2-\left(2^{\prime}, 3^{\prime}, 4^{\prime}\right.\right.$-trihydroxybutyl) quinoxaline] and QD-I $\left[\left(2^{\prime} S, 3^{\prime} R\right)\right.$. 2 - $\left(2^{\prime}, 3^{\prime}\right.$ - dihydroxy - $4^{\prime}$ - glucopyranosyloxybutyl $)$ quinoxaline] were the same specimens as those reported previously. ${ }^{3,6,11)}$ The latter specimen was obtained through the reaction of isomaltose with OPD.

\section{Experimental methods}

Reaction of carbohydrates and OPD. The conditions for the reaction were almost the same as those reported elsewhere. ${ }^{2,3,5)}$ The powdered carbohydrate specimen, OPD and $\mathrm{Na}_{2} \mathrm{SO}_{3}$ were each dissolved stepwise in a small volume of carbonate buffer $(0.2 \mathrm{M}, \mathrm{pH} 10)$, with nitrogen gas bubbling, to final concentrations of carbohydrate, as glucose units, OPD and $\mathrm{Na}_{2} \mathrm{SO}_{3}$ of about $5 \times 10^{-4} \mathrm{M}, 0.1 \mathrm{M}$ and $0.3 \mathrm{M}$, respectively. These solutions were heated at $100^{\circ} \mathrm{C}$ in the presence of oxygen. A sample of the reaction mixture was withdrawn as appropriate time intervals. For polarographic analysis, a portion of the solution was diluted with the same buffer as above.

For liquid chromatography, a 10-fold higher concentration of a sample solution was heated for different periods as above. One milliliter of each heated reaction mixture was withdrawn, and then $0.1 \mathrm{ml}$ of acetic acid was added to adjust the $\mathrm{pH}$ of the solution to $c a$. 4. This sample was applied to a liquid chromatographic column $(0.9 \times 100 \mathrm{~cm})$ of Dowex $1 \times 8$ (acetate form, $400 \mathrm{mesh}$ ). Compounds on the column were eluted with $0.4 \mathrm{M}$ acetate buffer ( $\mathrm{pH} \mathrm{4.4)}$ at the flow rate of $25 \mathrm{ml} / \mathrm{hr}$. The absorbance of each fraction $(5 \mathrm{ml})$ was recorded with a UV spectrophotometer at 320 $\mathrm{nm}$. Laminari-oligosaccharides were prepared from curdlan by partial acetolysis, ${ }^{12)}$ subsequent deacetylation and then cellulose column chromatography. ${ }^{13)}$ Laminari-biose (LG-2), -triose (LG-3), -tetraose (LG-4), -pentaose (LG-5) and -hexaose (LG-6) were prepared as lyophilized samples.

Polarograms were taken with a Yanagimoto polarograph (model 102). The dropping mercury electrode had the following characteristics: the flow rate of mercury $(m)$ was 2.61 $\mathrm{mg} / \mathrm{sec}$, and the drop time $(t)$ was $3.2 \mathrm{sec}$ in an open circuit in distilled water with a $60-\mathrm{cm}$ high mercury reservoir in a 10-ml Y-type cell.

Ion-exchange column chromatography was performed with a Yanagimoto nucleic acid analyzer (modified type LC-100). Compounds on the column were eluted with acetate buffer $(0.4 \mathrm{M}, \mathrm{pH} 4.4)$ at $45^{\circ} \mathrm{C}$ at the rate of $25 \mathrm{ml} / \mathrm{hr}$. One $\mathrm{ml}$ of the reaction mixture was neutralized with $0.1 \mathrm{ml}$ of acetic acid and then loaded on the column.

The UV spectrum was recorded on a Hitachi EPS 3 spectrophotometer. Thin-layer chromatography (TLC) and paper chromatography were performed as reported previously. ${ }^{3,5,7)}$

Reaction of curdlan and $O P D$. For the preparation of quinoxaline derivatives from curdlan, $4 \mathrm{~g}$ of a sample was moistened with a minimum volume of ethanol, and then $100 \mathrm{ml}$ of $\mathrm{NaOH}$ was added. Then $400 \mathrm{ml}$ of $0.5 \mathrm{~N}$ $\mathrm{Na}_{2} \mathrm{CO}_{3}, \quad 0.1 \mathrm{~mol}$ of $\mathrm{OPD}$ and $0.1 \mathrm{~mol}$ of $\mathrm{Na}_{2} \mathrm{SO}_{3}$ were added to the solution, with $\mathrm{N}_{2}$ gas bubbling; the solution was made to $1000 \mathrm{ml}$ and then refluxed for $15 \mathrm{hr}$. After being heated, the reaction mixture was cooled in an ice-water bath and then extracted with ether and 1-butanol $(\mathrm{BuOH})$. The $\mathrm{BuOH}$ extract was evaporated to dryness under reduced pressure, and the residue was dissolved in a minimum volume of acetone. The solution was left overnight in a refrigerator to afford colorless crystals $(1.2 \mathrm{~g})$. This crystaline compound was identified as G-1 by means of several analytical methods.

\section{RESULTS AND DISCUSSION}

\section{Quinoxaline formation from various glucans evaluated with a polarographic limiting current}

Figure 1A shows the time-courses polarographic limiting currents of quinoxalines formed from various glucans in an alkaline solution. Differences in the amounts of the quinoxalines arising from the linkages of glucans were observed. In order to discuss the details of quinoxaline formation, we must examine the 


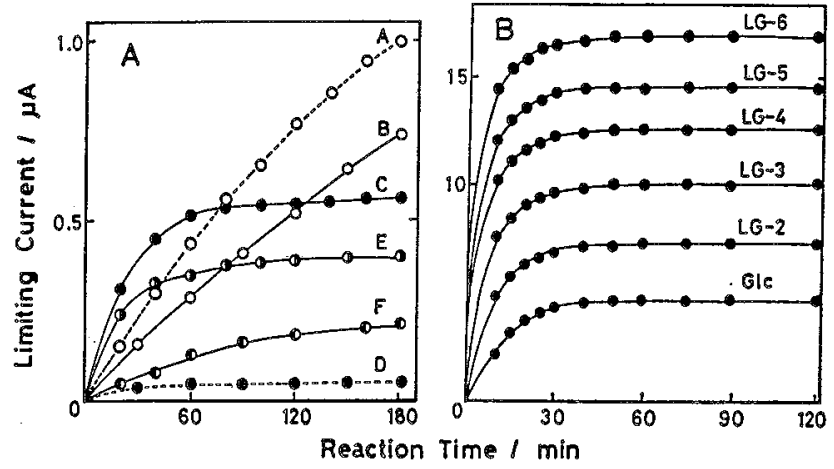

Fig. 1. Changes in the polarographic limiting currents of quinoxalines derived from various polysaccharides (A) and laminari-oligosaccharides (B) with time.

One of the glucan samples listed below, $0.1 \mathrm{M}$ OPD and 0.3 $\mathrm{M} \mathrm{Na}_{2} \mathrm{SO}_{3}$ were each dissolved in $0.2 \mathrm{M}$ carbonate buffer $(\mathrm{pH}$ 10) and then heated under deoxygenated conditions for $30 \mathrm{~min}$ at $100^{\circ} \mathrm{C}$. A $1-\mathrm{ml}$ portion of each sample was diluted to the concentration of $2.5 \times 10^{-3} \mathrm{M}$ with $0.4 \mathrm{M}$ acetate buffer (pH 4.4), the solution was heated at $100^{\circ} \mathrm{C}$, and then a portion of the solution was subjected to polarography as described in MATERIALS AND METHODS. The following samples $(\mathrm{mg} / 100 \mathrm{ml})$ were used for the reaction: $A$, amylose $10 \mathrm{mg}\left(\overline{\mathrm{d} \cdot \mathrm{p}_{\cdot \mathrm{n}}}=117\right) ; B$, curdlan $10 \mathrm{mg}(\overline{\text { d.p. } \cdot \mathrm{n}}=400) ; \mathrm{C}$, dextran $100 \mathrm{mg}(\overline{\text { d.p.n }}=270) ; \mathrm{D}$, luteose $100 \mathrm{mg}\left(\overline{d_{\cdot} \mathrm{p}_{\cdot \mathrm{n}}}=5500\right) ; \mathrm{E}$, glycogen $100 \mathrm{mg}\left(\overline{\mathrm{d}_{\mathrm{f} \cdot \mathrm{p} \cdot \mathrm{n}}}=800\right)$; and $\mathrm{F}$, amylopectin $150 \mathrm{mg}\left(\overline{\mathrm{d} \cdot \mathrm{p}_{\cdot \mathrm{n}}}=5400\right)$.

For Fig. 1B, each of laminari-oligosaccharides used (GIc, LG-2, LG-3, LG-4, LG-5 and LG-6) was dissolved in the $0.2 \mathrm{M}$ carbonate buffer $(\mathrm{pH} \mathrm{10)}$. The concentration of the glucans was made to $5 \times 10^{-4} \mathrm{M}$ with $\mathrm{N}_{2}$ bubbling. Other conditions were the same as in Fig. 1A.

properties of quinoxalines formed from various glucans, and determine whether the reaction proceeds regularly with time or ceases when a certain saturation level is attained. As described below, the quinoxalines that were obtained as the main products from an $\alpha-1,4$-glucan and $\beta$-1,3-glucan were isomers of each other. However, the structures of quinoxalines formed from dextran with $\alpha$-1,6-glucosidic linkages were considerably different from those formed from glycogen and amylopectin with both $\alpha-1,4$ and $\alpha-1,6$-linkages.

\section{Quinoxalines derived from $\beta$-1,3-glucan and $O P D$}

Figure $1 \mathrm{~B}$ shows the polarographic limiting currents of quinoxalines derived from laminaridextrins. The wave height due to limiting current of quinoxaline at $-0.87 \mathrm{~V}$ became stationary after the solution had been heated for $40 \mathrm{~min}$. Thereafter, no particular changes were observed. That is, the quinoxalines thus formed were quite stable even if heated for several hours. They comprised a mixture of several small quinoxaline derivatives. ${ }^{6,11}$ When the molar concentration of each laminari-oligosaccharide became the same in the reaction mixture with excess OPD, the wave height of each of the quinoxalines formed was proportional to number of glucose units in the glucan molecule after the completion of the reaction. However, for laminaribiose, the wave height was not double that of glucose, but only 1.5fold. This indicates that G-1 formed from the non-reducing-end residue of laminaribiose accounted for only about half of the quinoxalines 


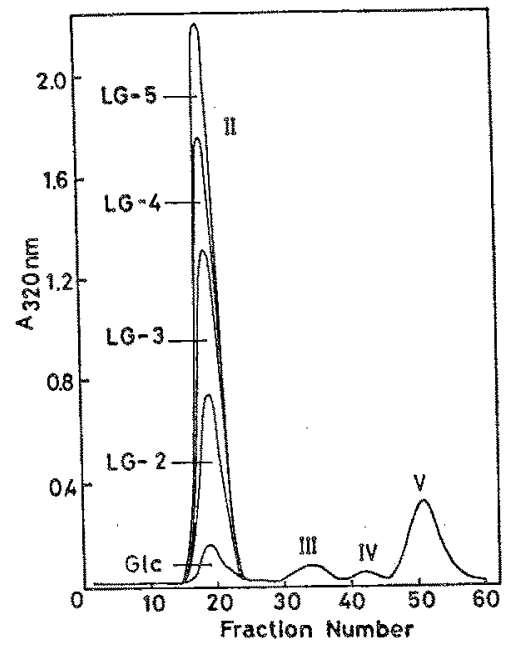

Fig. 2. Elution profiles on ion-exchange chromatography of quinoxalines derived from various laminari-oligosaccharides.

The concentration of each laminarioligosaccharide was $2.5 \times 10^{-3} \mathrm{M}$; they were heated at $100^{\circ} \mathrm{C}$ for $2 \mathrm{hr}$, as described in Fig. 1. One milliliter of acetic acid was added to $3 \mathrm{ml}$ of the sample, and then the mixture was put on an ion-exchange column $(0.9 \mathrm{~cm} x$ $100 \mathrm{~cm}$ ) of Dowex $1 \times 8$ (acetate form) with elution with $0.4 \mathrm{M}$ acetate buffer $\left(\mathrm{pH} 4.4\right.$ ) at $45^{\circ} \mathrm{C}$.

formed from the reducing end residue. After heating of glucose under the alkaline conditions, at least six quinoxaline derivatives were detected on TLC and HPLC analysis. ${ }^{11}$ Laminari-oligosaccharides (LG-2, LG-3, LG-4 and LG-5) and OPD (same number of moles) were heated, and the products were separated by ion-exchange column chromatography (Fig. 2). The quinoxaline corresponding to peak II increased with the increase in the degree of polymerization, but the other peaks did not. It is necessary to identify the structure of the peak II quinoxaline to clarify the reaction mechanism for $\beta-1,3$-glucan and OPD. For this purpose, this compound in the heated solution was extracted with $\mathrm{BuOH}$. After removal of the $\mathrm{BuOH}$ layer under reduced pressure, the residue was dissolved in acetone and then stored in a refrigerator, where it crystallized as colorless needles. Inspection of the data on the $m p$, IR spectrum, $R_{f}$ value and NMR spectrum of the peak II compound showed that the quinoxaline was $\left(2^{\prime} S, 3^{\prime} R\right) \cdot 2-\left(2^{\prime}, 3^{\prime}, 4^{\prime}\right.$-trihydroxy.

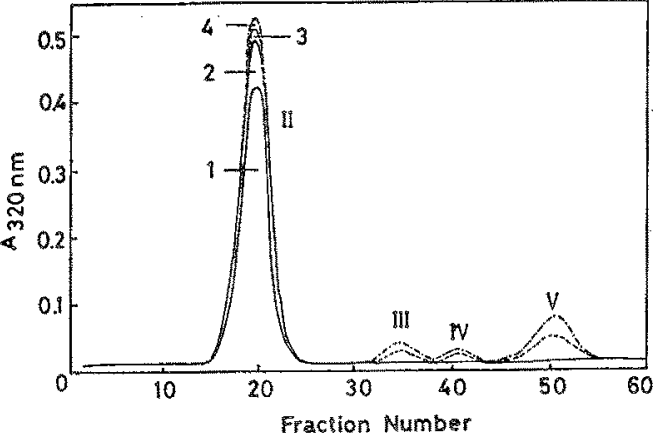

Fig، 3. Ion-exchange chromatograms of quinoxalines derived from laminaritetraose at various reaction times.

Laminaritetraose $\left(6.25 \times 10^{-4} \mathrm{M}\right)$ was dissolved in $0.2 \mathrm{M}$ carbonate buffer ( $\mathrm{pH} 10)$, and then OPD (0.1 M) and $\mathrm{Na}_{2} \mathrm{SO}_{3}(0,3 \mathrm{M})$ were added. The solution was heated for the specified times under deoxygenat. ed conditions. Other conditions were the same as in Fig. 1.

butyl)quinoxaline (G-1)., In this structure, the carbonyl groups of $\mathrm{C}-1$ and $\mathrm{C}-2$ of the glucose residue would condense with $\mathrm{OPD}$ to give quinoxaline derivatives. To examine the quinoxalines derived from the reducing-end residue (Fig. 3), laminaritetraose was studied over time for the formation of quinoxaline. We found that the reducing-end residue of laminaritetraose reacts with $\mathrm{OPD}$, and then the 1,3-inner chain linkages are split. When this degradation reaction proceeds and reaches the non-reducing end residue, the residue is liberated from the glucosidic linkage. At this stage, the glucose residue may be converted into various keto- and enol-forms under alkaline-heated conditions. From the dicarbonyl compounds thus formed, the corresponding quinoxaline derivatives were formed. Since there is excess OPD in the reaction mixture, the rate of quinoxaline formation is proportional to the amount of reducing-end residues, and the reaction proceeds in an almost pseudo-zeroorder manner. Therefore, from the rate of the reaction, it is possible to calculate the mean number-average molecular weight, i.e., the ratio of reducing-end glucose residues to nonreducing glucose residues.

Turanose and 3-O-methyl-D-glucose, which are substituted by one glucose residue or 


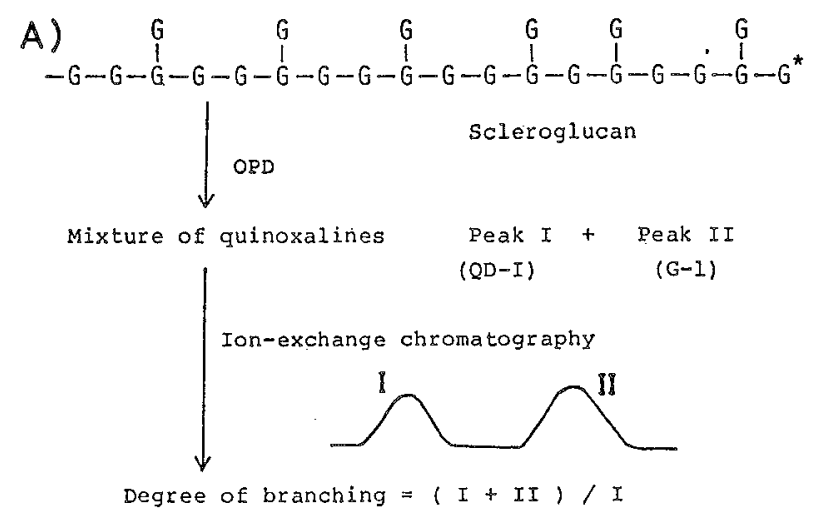

B)

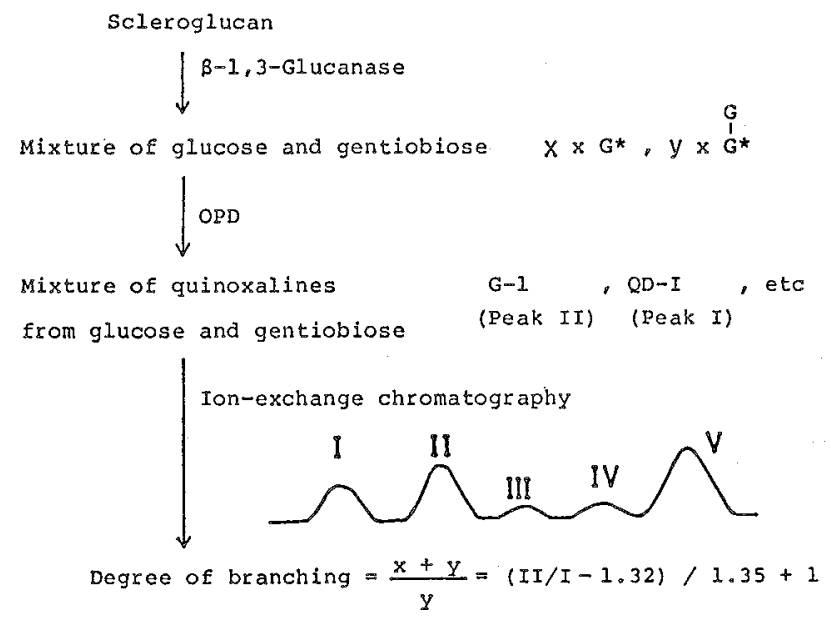

Fig. 4. Estimation of the degree of branching of scleroglucan by the direct OPD method (A) and the same method together with $\beta$-1,3-glucanase treatment (B).

* Denotes a reducing-end residue.

methoxyl residue, respectively, at the $\mathrm{C}-3$ position, gave the corresponding quinoxaline derivatives.

\section{Quinoxalines derived from scleroglucan and $O P D$}

Scleroglucan is a homoglucan that has $\beta-1,3$ linkages in its main chain and $\beta-1,6$ linkages in its banched chains. The structures of glucan from Claviceps fusiformis, ${ }^{14)}$ schizophyllan, ${ }^{15)}$ sclerotan from Sclerotinia libertiana, ${ }^{16)}$ etc., are similar.

We attempted to determine the degree of branching in these glucans. Buck et al. ${ }^{8)}$ calculated the degree of branching of the glucan from Claviceps fusiformis by using $\beta$-1, 3-glucanase, which degrades scleroglucan to glucose and gentiobiose. These workers reported that the ratio of branching varies with different cultural conditions. ${ }^{8)}$ Schizophyllan has one single branched glucose residue for every three moles of glucose residues in its main chain. ${ }^{153}$ Takeuchi and Kitahara reported that two or three branched chains are attached to 10 glucose core units in scleroglucan. ${ }^{16)}$ We studied the ratio of branching by the alkaline OPD method. As shown in Fig. $4 \mathrm{~A}$, the reaction mode: is similar to that in the case of curdlan; that is, quinoxaline $\mathrm{G} \cdot \mathrm{1}^{3,11}$ is formed regularly. However, from scleroglucan, two kinds of 
quinoxalines are formed; one from the glucose unit and the other from the gentiobiose unit. ${ }^{3,6)}$ The ratio of peak II (G-1) to peak I (QD-I) corresponds to that of glucose and gentiobiose liberated. Therefore, the degree of branching of scleroglucan is the same as the ratio of the peak areas of $(\mathrm{I}+\mathrm{II}) / \mathrm{I}$.

The alkaline solution of scleroglucan was considerably viscous and the rate of the reaction was slow. The reaction took a pretty long time to reach the non-reducing end residue from the reducing-end residue of the polymer. After $5 \mathrm{hr}$ heating, the non-degraded part of the polymer was removed by centrifugation, and the supernatant was applied to an ion-exchange column to determine the degree of branching. Assuming that the branching points are distributed evenly in the polymer, some reliable results must have been obtained. In this experiment, we used both the enzymatic method with $\beta-1,3$ glucanase and the alkaline OPD method to evaluate the degree of branching. This $\beta-1,3$ glucanase is an exo-type enzyme, and shows no hydrolytic activity on $\beta-1,6$ linkages. The course of hydrolysis of scleroglucan ( $5 \mathrm{mg}$ ) was followed with $\beta-1,3$ glucanase $(0.33 \mathrm{mg})$ in $0.1 \mathrm{M}$ acetate buffer $(\mathrm{pH} 5.5)$ for $40 \mathrm{hr}$. Paper chromatography of the complete hydrolyzate showed only two spots of glucose and gentiobiose (data not shown). Kikumoto et $a l_{.}{ }^{15)}$ and Buck et $a l^{8)}$ determined the amounts of each TLC spot after colorization with phenol-sulfuric acid. However, the quantitative method is neither easy nor very reliable. The OPD method is convenient for direct measurements without any complicated preparation. The results with the OPD method for scleroglucan treated with $\beta-1,3$ glucanase are shown in Fig. 4B. Peak I was formed from gentiobiose only, and the empirically estimated yield was $0.2 \mathrm{~mol}$ per mole of gentiobiose. Likewise, $0.27 \mathrm{~mol}$ of peak II was formed from one mol of free glucose and $0.264 \mathrm{~mol}$ from gentiobiose. The ratio of the peak areas of II/I, which was obtained for the scleroglucan treated with $\beta$-1,3-glucanase, can be expressed as:

$$
[0.264(\mathrm{Gen})+0.27(\mathrm{Glc})] / 0.20(\mathrm{Gen}) \text {. }
$$

If we hypothesize that $\mathrm{X}$ moles of glucose and $Y$ moles of gentiobiose are formed from one mol of scleroglucan, the degree of branching (D. B.) is as follows:

$$
\begin{aligned}
\text { D. B. }= & (\mathrm{X}+\mathrm{Y}) / \mathrm{Y}=\mathrm{X} / \mathrm{Y}+1 \\
\mathrm{II} / \mathrm{I}= & 0.264(\mathrm{Gen}) / 0.20(\mathrm{Gen}) \\
& +0.270(\mathrm{Glc}) / 0.20(\text { Gen }) \times \mathrm{X} / \mathrm{Y} \\
= & 1.32+1.35 \times \mathrm{X} / \mathrm{Y} \ldots \ldots \ldots \ldots \ldots \ldots
\end{aligned}
$$

Here, we define the degree of branching as the ratio of the total $\beta-1,3$ glucosidic chains to the number of $\beta-1,6$ glucosidic branches. From equation 2 , the value of $X / Y$ was replaced by (II/I-1.32)/1.35. If we substitute this $X / Y$ into equation 1 , the value of $\mathrm{D} . \mathrm{B}$. is represented by:

$$
\text { D. } \begin{aligned}
\mathrm{B} . & =(\mathrm{X}+\mathrm{Y}) / \mathrm{Y}=\mathrm{X} / \mathrm{Y}+1 \\
& =(\mathrm{II} / \mathrm{I}-1.32) / 1.35+1
\end{aligned}
$$

The degrees of branching of sclerotan, scleroglucan and schizophyllan were evaluated by the two methods, i.e., the direct OPD method and the OPD method combined with the enzymic method. In the case of sclerotan, the d.p. of the sample used was not large enough, so we must take into account the factor for the non-reducing end residue, i.e., D. B.= $[\mathrm{I}+\mathrm{II}+0.97 \times \mathrm{V}] / \mathrm{I}$. For materials with sufficiently large molecular weights, the value of $0.97 \times \mathrm{V}$ can be neglected.

The results obtained on enzyme hydrolysis did not contradict those for schizophyllan ${ }^{15)}$ and sclerotan. ${ }^{16)}$ All of these results indicate that this alkaline OPD method seems to be an efficient method for evaluating the degree of branching, the preparation of the sample is simple, and the method is easily applicable.

The degree of branching of scleroglucan from strain 5913 was found to be 2.66 by the alkaline

Table 1. Determination of the branching of various $\beta$-1,3-glucans with single glucose units attached at the 6 position $(\beta-1,6)$.

\begin{tabular}{lcc}
\hline Glucans & $\begin{array}{c}\text { Direct OPD } \\
\text { method }\end{array}$ & $\begin{array}{c}\beta-1,3 \text {-glucanase } \\
\text { treated }\end{array}$ \\
\hline Scleroglucan & & \\
I. F. O. 5292 & 2.34 & 2.33 \\
I. F. O. 5913 & 2.66 & 2.55 \\
I. F. O. 5913a) & 3.89 & - \\
Sclerotan ${ }^{\text {b) }}$ & 2.93 & 2.95 \\
Schizophyllan & 2.77 & 2.57 \\
\hline
\end{tabular}

a) With medium containing $5 \%$ sucrose.

b) D. B. $=(\mathrm{I}+\mathrm{II}+0.97 \mathrm{~V}) / \mathrm{I}\left(\mathrm{DP}_{\mathrm{n}}\right.$ of sclerotan: 16$)$. 
OPD method (Table 1). This means that one single branched glucosyl groups are attached, one per 2.66 residues of the $\beta$-1, 3 main-chain. This value varied with the cultural conditions; it was 3.89 in $5 \%$ sucrose medium. For scleroglucan 5292, it was 2.34. This latter value agreed well with the reported value, ${ }^{15}$ but was somewhat lower than that reported by Johnson et $a{ }^{17)}$ (D. B. $=3.00$ ). This might be due to the different products with different cultural conditions ${ }^{8)}$ or microbial species.

The mechanism involved in the alkaline degradation of carbohydrate is very complicated. However, in the presence of excess OPD and deoxygenated conditions, dicarbonyl compounds condense to give quinoxaline derivatives which are specific to the original linkages. The characteristics and quantities of the quinoxalines formed provide some information on the structure of glucans. With this method, quinoxaline derivatives were only formed from the reducing-end residues of the glucan. If there are some branched chains in the glucan, quinoxalines with branched residues in their structures are formed. Therefore, we can investigate problems concerning the branched and main chain residues. For the separation of quinoxalines G-1 from 1, 3-linkages and M-1 from 1, 4-linkages, ${ }^{11)}$ elution on an ion-exchange column of Dowex $1 \times 8$ was not efficient. As was reported previously, ${ }^{6)}$ these quinoxalines can be almost completely separated after acetylation of their $\mathrm{OH}$ groups. For estimation of the degree of polymerization from the peak area on the chromatogram, considerable inaccuracy is inevitable with such small responses of the quinoxaline peak derived from non-reducing end residues, when highly polymerized samples $(\overline{\text { d.p. }} \mathrm{n}=20)$ are subjected to the reaction. However, for the measurement of the d.p. $n$ of a linear polysaccharide, the reaction proceeds in a nearly zero-order manner. To measure the total quinoxalines formed, polarography is convenient. However, when high molecular weight quinoxalines are formed in the reaction mixture, this method is not recommended, while the TLC method may be most suitable.

In conclusion, we presented a semi-empirical formula for the quantitative relationships between the degree of polymerization and quinox- alines formed from some $\beta-1,3$ glucans. We could estimate the ratio of branching and the main-chain residues of scleroglucans, and could easily establish that the ratio of branching varies with the cultural conditions.

\section{REFERENCES}

1) M. TAKagi, Y. Gotoh, R. Hosogaki, S. Amano and S. ONO: Stärke, 20, 215-224 (1968).

2) M. Takagi, M. Mizutani, I. Matsuda and S. ONO: Agric. Biol.Chem., 35, 793-796 (1971).

3) M. TAkagi, M. Mizutani and K. Tsuchiya: Bull. Univ. Osaka Pref., 24, 43-50 (1972).

4) M. Takagi, K. Tsuchiya, M. Kuriyama, K. MiYANO and K. HAYASHI: Abstract Book of the Eighth International Symposium on Carbohydrate Chemistry, Kyoto, p. 116 (1976).

5) N. Morita, K. Hayashi, M. TAKagi and K. MrYano: Agric. Biol.Chem., 47, 757-763 (1983).

6) M. Takagi, Y. Daido and N. Morita: Anal. Sci., 2, 281-285 (1986).

7) T. Harada, A. Misaki and H. Saito: Arch. Biochem. Biophys., 124, 292-298 (1968).

8) K. W. BuCK, A. W. CHEN, A. G. DiCKERSON and E. B. Chain: J. Gen. Microbiol., 51, 337-352 (1968).

9) Y. TAKeuchi and M. Kitahara: Nippon Nōgeikagaku Kaishi, 35, 468-474 (1961).

10) M. MAdA, K. HIRANo, Y. KimuRA and K. NODA: Nippon Nōgeikagaku Kaishi, 44, 393400 (1970).

11) N. Morita, M. Mizutani, K. Hayashi, M. Kirihata, I. IChIMoto, H. UEDA and M. TAKAgI: Bull. Univ. Osaka Pref., 35, 59-70 (1983).

12) P. Perchemlides, T. Osawa, E. A. Davidson and R. W. JEAnloz: Carbohydr. Res., 3, 463477 (1967).

13) J. A. ThomA, H. B. Wright and D. French: Arch. Biochem. Biophys., 85, 452-460 (1959).

14) L. L. WALlen, R. A. RHODES and H. R. SHUlKe: Appl. Microbiol., 13, 272-278 (1965).

15) S. Kikumoto, T. Miyajima, K. Kimura, S. OKuBo and N. KomATsu: Nippon Nögeikagaku Kaishi, 45, 162-168 (1971).

16) Y. TAkeuchi and M. Krtahara: Agric. Biol. Chem., 30, 523-528 (1966).

17) J. Johnson, Jr., S. Kirkwood, A. MisAKI, T. E. Nelson, J. V. ScAletti and F. Smith: Chem. Ind., 820-822 (1963). 
アルカリ加熱により $\beta-1,3$ 㣘よび $\beta-1,3,-1,6$ 結合のグルカンから得られる キノキサリンのポーラログラフィー，液体 クロマトグラフィーによる分析

高木正之助，上屋和男，栗山雅夫， 宮野辟一，森田尚文 大阪府立大学農学部 (591 界市百舌鳥梅町) カードラン，スクレログルカン等の $\beta-1,3, \beta-1,6$ 結
合のグルカンをアルカリ性, 無酸素条件下, アルカリ ローフェニレンジアミン法により得られるキノキサリンを 液体クロマトグラフィ一，ポーラログラフィーで分析し， グルカンの分枝度を検討した。ラミナリデキストリン, カードランからは，主鎖の $\beta-1,3$ 結合火由来する $(2$, $\left.3^{\prime} \mathrm{R}\right)-2-\left(2^{\prime}, 3^{\prime}, 4^{\prime}\right.$ ートリヒドロキシブチル) キノキサリン (G-1) 々非還元末端基に由来する数種のキノキサリンが 経時的に増大した．スクレログルカンでは，主鎖の 1,3 結合から G-1, 分枝糖鎖から QD-1 が得られ, これら の比から分枝度は $2.3 \sim 2.6$ と計算された。 この方法で 得られた值は，既報の值とよく一致した。 